\title{
Elektrod Superkapasitor daripada Komposit Karbon Teraktif dan Grafen dengan Perekat PVDF-HFP
}

(Supercapacitor Electrode from Activated Carbon and Graphene Composite with PVDF-HFP Binder)

\author{
Mohamad Redwani Mohd Jasni, Mohamad Deraman, Zalita Zainuddin*, Chia Chin Hua \& Ramli OMar
}

\begin{abstract}
ABSTRAK
Elektrod superkapasitor elektrokimia dwi-lapisan telah dihasilkan menggunakan serbuk karbon monolit teraktif (KMT) sebagai bahan pemula dan grafen sebagai bahan tambah. Elektrod telah disediakan dengan mencampurkan serbuk KMT dan grafen dengan peratus berat yang berbeza $(0,5,10,20$ dan $40 \%$ bt.) yang ditambah larutan polivinilidena fluoridaheksafluoropropilena (PVDF-HFP) sebagai agen perekat serta karbon hitam sebagai agen konduksian. Pencirian fizikal dijalankan ke atas elektrod dengan menggunakan kaedah pembelauan sinar-X (XRD) dan isoterma jerapan-nyahjerapan. Prestasi sel superkapasitor dengan elektrolit akueus $6 \mathrm{M} \mathrm{KOH} \mathrm{telah} \mathrm{diuji} \mathrm{menggunakan} \mathrm{kaedah} \mathrm{spektroskopi} \mathrm{impedans}$ elektrokimia (EIS), voltametri berkitar (CV) dan cas-discas galvanostatik (GCD). Sel superkapasitor dengan bahan tambah grafen $5 \%$ bt. (KMT05) didapati mempunyai kapasitans tentu yang tertinggi $\left(172 \mathrm{~F}^{-1}\right)$, tenaga tentu yang tertinggi (11 $\left.\mathrm{Wh} \mathrm{kg}^{-1}\right)$, kuasa tentu yang terting gi (196.13 W kg-1), masa gerak balas terendah (2 s) serta rintangan pemindahan cas terendah (2.4 $\Omega$ ) berbanding sel-sel yang lain. Ini menunjukkan bahawa bahan tambah grafen $5 \%$ bt. adalah optimum untuk meningkatkan prestasi sel. Hasil ini selaras dengan saiz mikrohablur serta luas permukaan tentu KMT05X yang lebih besar berbanding KMT tanpa bahan tambah grafen (KMTOOX).
\end{abstract}

Kata kunci: Elektrolit akueus ; elektrod perekat; grafen; karbon monolit teraktif; serbuk karbon swa-merekat

ABSTRACT

Electrochemical double-layer supercapacitor electrodes were produced using an activated carbon monolith (ACM) powder as the precursor and graphene as the additive. Electrodes were prepared by mixing ACM powder and graphene with different weight percentage (0,5, 10, 20 and $40 \mathrm{wt}$.\%) which were added with poly-vinylidene fluoride-hexafluoropropylene (PVDF-HFP) solution as a binding agent and carbon black as a conductive agent. Physical characterization was carried out on the electrodes by using an X-ray diffraction (XRD) and adsorption-desorption isotherms methods. Supercapacitor cells performance using $6 \mathrm{M} \mathrm{KОН} \mathrm{aqueous} \mathrm{electrolyte} \mathrm{were} \mathrm{tested} \mathrm{using} \mathrm{electrochemical} \mathrm{impedance} \mathrm{spectroscopy} \mathrm{(EIS),}$ cyclic voltammetry $(\mathrm{CV})$ and galvanostatic charge discharges (GCD) methods. Supercapacitor cell with 5 wt. \% graphene additive (KMT05) was found to have the highest specific capacitance $\left(172 \mathrm{~F} \mathrm{~g}^{-1}\right)$, highest specific energy $\left(11 \mathrm{Wh} \mathrm{kg}^{-1}\right)$, highest specific power $\left(196.13 \mathrm{~W} \mathrm{~kg}^{-1}\right)$, lowest response time $(2 \mathrm{~s})$, and lowest charge transfer resistance (2.4 $\Omega$ ) compared to other cells. This showed that $5 \mathrm{wt} . \%$ graphene additive is optimum for improving the cell performance. These results are compatible with the larger microcrystallites size and specific surface area of KMT05X have a larger compared to the KMT with no graphene additive (KMTOOX).

Keywords: Activated carbon monoliths; aqueous electrolyte; graphene; paste electrode; self-adhesive carbon grains

\section{PENGENALAN}

Banyak penyelidikan dan pembangunan telah dijalankan bagi meningkatkan prestasi peranti penyimpan tenaga seperti sel bahan api, bateri, kapasitor dan superkapasitor. Prestasi unggul superkapasitor ialah sumbangan daripada ketumpatan simpanan tenaga yang lebih tinggi berbanding dengan kapasitor. Selain itu, ketumpatan kuasanya juga lebih tinggi, kadar cas dan nyahcasnya adalah lebih cepat dan kitaran hidupnya adalah lebih lama daripada bateri. Kelebihan ini menjadikan superkapasitor antara pilihan yang menarik untuk kegunaan dalam pelbagai bidang penyimpanan tenaga yang memerlukan keupayaan kuasa yang tinggi, contohnya kenderaan elektrik, jentera dan peranti teknologi komunikasi. Komponen utama superkapasitor ialah elektrod, elektrolit, pemisah dan pengumpul arus. Pelbagai usaha penyelidikan telah dilakukan untuk meningkatkan prestasi tenaga dan kuasa superkapasitor. Prestasi superkapasitor boleh ditambah baik dengan memaksimumkan voltan tetingkap elektrolit (elektrolit akueus, organik \& cecair ionik) dan juga meningkatkan luas permukaan tentu elektrod (Gu \& Yushin 2014). Penggunaan elektrolit akueus adalah lebih praktikal dan berdaya maju berbanding dengan elektrolit organik dan cecair ionik (Zhong et al. 2015). Dalam konteks ini, adalah lebih strategik untuk membina elektrod superkapasitor yang melibatkan penggunaan elektrolit akueus.

Selain daripada karbon berliang, oksida logam dan polimer pengkonduksi turut digunakan sebagai bahan 
elektrod kerana dapat menunjukkan sifat pseudo-kapasitif yang wujud daripada proses faradaik, yang biasanya dikaitkan dengan kuasa yang lebih rendah dan tahap penahanan kapasitans yang tinggi (González et al. 2016). Setakat ini, karbon teraktif (KT) berliang telah digunakan secara meluas sebagai bahan elektrod kerana kos yang lebih rendah, luas permukaan tentu (SSA) yang lebih besar dan kestabilan kimia yang baik (Sevilla \& Mokaya 2014). Ia menunjukkan sifat kapasitans elektrik dwi-lapisan berdasarkan pengumpulan cas elektrostatik pada antara muka elektrod-elektrolit yang mempunyai luas permukaan yang tinggi dan menghasilkan sifat elektrokimia dan kestabilan kitaran yang sangat baik (González et al. 2016; Sevilla \& Mokaya 2014). Selain daripada SSA yang tinggi, ciri-ciri liang seperti taburan saiz liang, sambungan liang dan bentuk liang yang dimiliki oleh elektrod karbon adalah sangat sesuai untuk mencapai pengumpulan dan pengangkutan ion dengan lebih cekap sehingga membawa kepada ketumpatan tenaga dan kuasa yang lebih tinggi (Zhong et al. 2015). Oleh itu, KT yang mempunyai lebih banyak liang mikro seperti nanotiub karbon (CNT) dan grafen telah dicadangkan untuk dijadikan elektrod berkuasa tinggi dan bahan tambahan konduksian (Farma et al. 2013a; Ho 2014; Jiang et al. 2013).

Grafen merupakan bahan yang mempunyai struktur dua dimensi (2D) dengan ciri-ciri yang luar biasa seperti sifat haba, mekanik dan elektrik yang sangat baik; serta boleh memberikan kapasitans tentu teori yang maksimum $\sim 550 \mathrm{~F} \mathrm{~g} \mathrm{~g}^{-1}$ (Zhu et al. 2010). Walau bagaimanapun, biasanya nilai kapasitans tentu yang diukur berkurang sehingga $\sim 100-200 \mathrm{~F} \mathrm{~g} \mathrm{~g}^{-1}$ kerana SSAnya lebih rendah daripada nilai teori $\left(\sim 2630 \mathrm{~m}^{2} \mathrm{~g}^{-1}\right)$, disebabkan oleh timbunan lapisan bergrafit yang selari dengan kepingan satah grafen (Dong et al. 2012; Xu et al. 2013). Selain itu, kos pengeluaran grafen yang tinggi kerana kaedah sintesis yang rumit, menghadkan penggunaan grafen untuk projek berskala besar. Oleh kerana kelemahan grafen itu dan fakta bahawa KT mempunyai luas permukaan yang tinggi dan agak murah, manakala grafen boleh menawarkan kekonduksian elektrik yang tinggi, maka adalah wajar untuk menyediakan elektrod komposit dengan menggunakan grafen sebagai bahan tambah dan KT sebagai matriks untuk membangunkan elektrod superkapasitor yang baru.

Dalam kajian ini, penyediaan elektrod superkapasitor dwi-lapisan menggunakan serbuk karbon monolit teraktif (KMT) sebagai bahan pemula dan grafen sebagai bahan tambah elektrod serta perekat PVDF-HFP dilaporkan. Fungsi perekat PVDF-HFP yang ditambah adalah sebagai penghubung antara bahan dalam elektrod dengan pemungut arus bagi penghasilan sel superkapasitor. Banyak kajian melaporkan penggunaan perekat jenis poli(tetrafluoroetilena) (PTFE) (Chen et al. 2012; Fan et al. 2014; Jiang et al. 2013; Liu et al. 2016; Xie et al. 2016; Zheng et al. 2014; Zhou et al. 2017), tetapi dalam kajian ini PVDF-HFP dipilih kerana ia adalah bahan polimer yang mempunyai tahap kestabilan elektrokimia yang tinggi, daya ikatan yang kuat serta zarahnya mudah tersebar. Ia juga lebih stabil terhadap bahan karbon yang bersentuhan dengan pemungut arus serta menjadikannya agen perekat yang sangat sesuai (Barsykov \& Khomenko 2010; Wang et al. 2014). Kajian ini, memfokus kepada kesan modifikasi elektrod komposit terhadap peratus peningkatan nilai kapasitans tentu, tenaga tentu dan kuasa tentu.

\section{BAHAN DAN KAEDAH}

PENYEDIAAN DAN PENCIRIAN ELEKTROD KMT TANPA PEREKAT

Serabut tandan kelapa sawit (STKS) yang diguna dalam kajian ini dibekalkan oleh Ecofibre Technology Sdn. Bhd. Malaysia. Pelet KMT dihasilkan daripada serbuk karbon swa-merekat (SKSM) daripada STKS melalui kaedah pengkarbonan dan pengaktifan seperti yang dilaporkan oleh penyelidik terdahulu (Deraman et al. 2011, 2010; Farma et al. 2013b; Jasni et al. 2016a, 2016b; Taer et al. 2010). Terlebih dahulu pelet KMT dibasuh dengan asid hidroklorik $(\mathrm{HCl})$ bertujuan untuk menyingkirkan agen pengaktifan dan sebarang bendasing. Ini diikuti dengan proses meneutralkannya kembali menggunakan air suling sehingga pH7 tercapai (Wei et al. 2012). Kemudian, ia dikeringkan di dalam ketuhar pada suhu $80^{\circ} \mathrm{C}$ selama 24 jam. Pelet kering seterusnya dikisar untuk mendapatkan serbuk KMT yang halus (KMT00X). Serbuk KMT yang dikisar bersama dengan $5 \%$ bt. grafen (KMT05X) turut disediakan bagi melihat kesan grafen ke atas sifat fizikal KMT.

Pencirian fizikal seterusnya dilakukan ke atas keduadua sampel tersebut. Ujian belauan sinar-X dijalankan dalam julat sudut belauan $0^{\circ}$ hingga $60^{\circ}$ menggunakan meter pembelauan sinar-X (Bruker AXS Germany D8 Advance) dengan sinaran $\mathrm{CuK} \alpha(1.5406 \AA \AA)$. Data isoterma jerapan-nyahjerapan dicerap menggunakan porosimeter (ASAP 2010 Micromeritics) pada suhu $77 \mathrm{~K}$ dalam persekitaran gas $\mathrm{N}_{2}$. Analisis mikrostruktur telah dijalankan dengan merekod imej pada permukaan patahan keratan rentas bagi sampel KMT dengan menggunakan alat mikroskop imbasan elektron pancaran medan (FESEM) (model SUPRA PV 55).

PENYEDIAAN ELEKTROD BERPEREKAT DAN FABRIKASI SEL SUPERKAPASITOR SERTA PENCIRIAN ELEKTROKIMIA

Elektrod superkapasitor telah disediakan dengan menggunakan KMT sebagai bahan pemula, grafen sebagai bahan tambah, polivinilidena fluorida-heksafluoropropilena (PVDF-HFP, Sigma Adrich) sebagai bahan perekat dan karbon hitam sebagai agen konduksian. Komposisi peratus berat semua bahan dan label sampel sel superkapasitor adalah seperti yang ditunjukkan dalam Jadual 1. Serbuk KMT, grafen dan karbon hitam dicampur bersama dengan peratus yang ditetapkan dan dikisar dengan menggunakan mortar supaya menjadi sekata dan homogen. Campuran itu seterusnya ditambah dengan $10 \%$ bt. (5 mL) perekat PVDF-HFP yang telah dikacau dengan menggunakan pengacau magnet pada suhu bilik selama 
30 min. Beberapa titis aseton dimasukkan ke dalam campuran serbuk berserta perekat dan dikacau dengan menggunakan mortar bagi membentuk buburan. Proses salutan berus buburan dilakukan ke atas pemungut arus pita grafit (MNL Enterprise, 4051322) berukuran $1 \mathrm{~cm} \times$ $1 \mathrm{~cm}$ melalui teknik tuangan titisan bagi menghasilkan lapisan elektrod yang sekata pada permukaan pemungut arus. Elektrod di atas pemungut arus dikeringkan dalam ketuhar pada suhu $70^{\circ} \mathrm{C}$ selama 24 jam. 5 mg serbuk KMT selepas dikeringkan (tanpa perekat, karbon hitam dan pemungut arus) digunakan untuk penentuan kapasitans tentu, kuasa tentu dan tenaga tentu (bagi elektrod tunggal). Lima sel superkapasitor simetri kemudiannya difabrikasi menggunakan pengumpul arus pita grafit berelektrod, pemisah Celgard polipropilena (3501 LLC) berketebalan $25 \mu \mathrm{m}$ (Nor et al. 2015) dan elektrolit KOH dengan kepekatan 6 M. Setiap sel disambung kepada pemegang sampel yang direka khas untuk ujian elektrokimia.

Ujian CV (julat voltan daripada 0 hingga $1 \mathrm{~V}$ dengan kadar imbasan 1 hingga $100 \mathrm{mV} \mathrm{s}^{-1}$, EIS (julat frekuensi $10^{-1}$ kepada $10^{-6} \mathrm{~Hz}$ ) dan GCD (julat voltan 0 hingga $1 \mathrm{~V}$ dengan ketumpatan arus $10 \mathrm{~mA} \mathrm{~cm}^{-2}$ ) telah dijalankan ke atas sel superkapasitor dengan menggunakan alat antara-mukaelektrokimia Solartron 1286. Nilai kapasitans tentu $\left(C_{s p}\right)$, kuasa tentu $(P)$, tenaga tentu $(E)$ dan parameter elektrik lain seperti rintangan elektrolit $(E S R / R)$, rintangan pemindahan cas $\left(R_{c t}\right)$, masa gerak balas $\left(\tau_{o}=1 / f_{o}, f_{o}\right.$ mewakili frekuensi gerak balas) telah dianggarkan mengikut prosedur lazim (Ke \& Wang 2016). Kapasitans tentu elektrod tunggal, $C_{s p}$ telah ditentukan daripada data EIS dengan menggunakan persamaan berikut:

$$
C_{s p}=2\left(\frac{C}{m}\right)=-\frac{1}{\pi f Z^{\prime \prime} m}
$$

dengan $C=\left(-\frac{1}{2 \pi f Z^{\prime \prime}}\right) ; f$ ialah frekuensi; $Z^{\prime \prime}$ ialah impedans khayalan pada $f$ dan $m$ ialah jisim elektrod tunggal. $C_{s p}$ juga telah ditentukan menggunakan data $\mathrm{CV}$ dan GCD dengan menggunakan persamaan berikut:

$$
\begin{aligned}
& C_{s p}=\frac{2 C_{s e l}}{m} \\
& C_{s p}=\frac{2 i}{(\Delta V / \Delta t) m}
\end{aligned}
$$

dengan $C_{s e l}=\frac{\oint i d V}{2 V s}$ adalah kapasitans sel keseluruhan; $\oint i d V$ ialah luas di bawah lengkung CV dan dirujuk sebagai cas voltametri; $V$ ialah beza keupayaan tetingkap; $s$ ialah kadar imbasan $\left(\mathrm{Vs}^{-1}\right)$; $\Delta t$ ialah masa nyahcas; $i$ ialah arus nyah cas dan $\Delta V$ ialah voltan.

Kuasa tentu, $P$ dan tenaga tentu, $E$ boleh dikira daripada data GCD dengan menggunakan persamaan berikut (Ban et al. 2013; Tsay et al. 2012):

$$
\begin{aligned}
& P=\frac{V i}{m} \\
& E=\frac{V i d T}{m}
\end{aligned}
$$

dengan $V$ ialah voltan yang tidak termasuk susutan nilai $i R$ ( $R$ ialah rintangan dalam) pada permulaan masa nyahcas; $R$ ialah rintangan dalam dan $t$ ialah masa. Nilai rintangan sesiri setara $(E S R)$ sel juga boleh ditentukan daripada susutan nilai $i R$.

\section{KEPUTUSAN DAN PERBINCANGAN}

\section{SIFAT FIZIKAL SERBUK KMT}

Rajah 1 menunjukkan spektrum XRD bagi serbuk KMT00X dan KMT05X. Bagi KMT00X, terdapat dua puncak lebar pada sudut pembelauan antara $\sim 27^{\circ}$ dan $\sim 44^{\circ}$ yang mewakili satah pembelauan (002) dan (100) yang menunjukkan ciri struktur karbon turbostratik (Jasni et al. 2017; Sulaiman et al. 2016; Xu et al. 2016). Spektrum KMT05X pada $\sim 44^{\circ}$ pula menunjukkan peningkatan keamatan puncak tajam (002) yang jelas dengan penambahan grafen. Kedudukan puncak dan kelebaran luas puncak yang berubah sedikit dipengaruhi oleh proses pengaktifan kimia atau pengaktifan fizikal yang dialami oleh sampel tanpa bahan tambah dan sampel yang mempunyai bahan tambah (Deraman et al. 2001; Dolah et al. 2014; Farma et al. 2013b).

Jarak antara satah $\left(\mathrm{d}_{002}, \mathrm{~d}_{100}\right)$ bagi hablur turbostratik KMT telah dihitung daripada puncak belauan (002) dan (100) menggunakan Hukum Bragg $(\mathrm{n} \lambda=2 \mathrm{~d} \sin \Theta)$. Dimensi mikrohablur iaitu ketinggian timbunan, $L_{c}$ dan kelebaran timbunan, $L_{a}$ seterusnya dihitung menggunakan persamaan Debye-Scherrer $\left(L_{c}=0.89 \lambda / \beta \cos \Theta\right.$ dan $L_{a}=1.89 \lambda / \beta \cos \Theta$, dengan $\beta$ adalah sama dengan

JADUAL 1. Komposisi peratus berat serbuk KMT, grafen, perekat dan karbon hitam bagi elektrod komposit

\begin{tabular}{lcccc}
\hline Label & $\begin{array}{c}\text { KMT } \\
(\% \text { bt. })\end{array}$ & $\begin{array}{c}\text { Grafen } \\
(\% \text { bt. })\end{array}$ & $\begin{array}{c}\text { PVDF-HFP } \\
(\% \text { bt. })\end{array}$ & $\begin{array}{c}\text { Karbon hitam } \\
(\% \text { bt. })\end{array}$ \\
\hline KMT00 & 80 & 0 & 10 & 10 \\
KMT05 & 75 & 5 & 10 & 10 \\
KMT10 & 70 & 10 & 10 & 10 \\
KMT20 & 60 & 20 & 10 & 10 \\
KMT40 & 40 & 40 & 10 & 10 \\
\hline
\end{tabular}


lebar puncak pada separuh ketinggian puncak $L_{c}$ dan $L_{a}$ (Awitdrus et al. 2010). Nilai parameter struktur yang telah ditentukan daripada data XRD ditunjukkan dalam Jadual 2. Perubahan kecil didapati berlaku pada nilai $d_{002}$ dan $d_{100}$, manakala perbezaan ketara ditunjukkan oleh nilai $L_{c}, L_{a}, L_{c} / L_{a}$ dan $L_{c} / d_{002}$. Keputusan ini menunjukkan bahawa saiz mikrohablur karbon dalam elektrod berubah apabila elektrod mempunyai bahan tambah $5 \%$ bt. grafen. Perubahan yang serupa ini juga dapat diperhatikan dalam kajian Dolah et al. (2014) (a yang telah menambah $3 \%$ bt. CNT dalam karbon teraktif. Modifikasi kesan radiasi yang dilakukan ke atas monolit hijau sebelum proses pengkarbonan dan pengaktifan terhadap karbon teraktif turut menunjukkan corak yang sama iaitu $L_{c}$ meningkat manakala $L_{a}$ berkurang (Nor et al. 2015).

Imej FESEM pada permukaan patahan dalam elektrod KMT00X dan KMT05X telah ditunjukkan pada Rajah 1(b) dan Rajah 1(c) dengan menggunakan skala pembesaran 50,000 kali. Morfologi kedua-dua sampel ini menunjukkan taburan jaringan liang terbuka yang sekata dengan liang yang lebih banyak dan besar bagi sampel KMT05X. Ini selaras dengan keputusan dalam Jadual 2.
Rajah 2(a) menunjukkan isoterma jerapannyahjerapan nitrogen bagi serbuk KMT00X dan KMT05X. Berdasarkan pengelasan IUPAC, kedua-dua lengkung memperlihatkan gelung histeresis dan ini menunjukkan yang serbuk KMT mempunyai liang mikro (jenis I) dan liang meso (jenis IV) (Qu 2002; Sing 1985). Kewujudan gelung histeresis berkait rapat dengan kondensasi kapilari dan pengambilan gas yang terhad pada julat $P$ / $P_{o}$ (tekanan relatif) yang tinggi. Kajian oleh Kim et al. (2013) menggunakan karbon berasaskan grafen teraktif memperoleh gelung histeresis pada isoterma jenis IV yang menunjukkan kehadiran liang meso.

Rajah 2(b) menunjukkan taburan saiz liang bagi elektrod KMT00X dan KMT05X. Daripada model BarretJoyner Halenda (BJH), didapati bahawa taburan saiz liang adalah meliputi saiz liang mikro $(<2 \mathrm{~nm})$, liang meso $(2-50 \mathrm{~nm})$ dan liang makro (> $50 \mathrm{~nm})$. Secara keseluruhannya, KMT05X mempunyai jumlah isi padu liang lebih banyak berbanding KMT00X. Ini menunjukkan bahawa kehadiran grafen dalam karbon teraktif telah memberi kesan kepada struktur keliangan elektrod. Kehadiran puncak lebar pada kedudukan sekitar $70 \mathrm{~nm}$

JADUAL 2. Nilai parameter struktur hablur serbuk KMT

\begin{tabular}{lcccccc}
\hline Sampel & $\mathrm{d}_{002}(\mathrm{~nm})$ & $\mathrm{d}_{100}(\mathrm{~nm})$ & $\mathrm{L}_{\mathrm{c}}(\mathrm{nm})$ & $\mathrm{L}_{\mathrm{a}}(\mathrm{nm})$ & $\mathrm{L}_{\mathrm{c}} / \mathrm{L}_{\mathrm{a}}$ & $\mathrm{L}_{\mathrm{c}} / \mathrm{d}_{002}$ \\
\hline KMT00X & 3.57 & 2.06 & 8.06 & 52.34 & 0.15 & 2.26 \\
KMT05X & 3.48 & 2.05 & 10.07 & 43.21 & 0.23 & 2.89 \\
\hline
\end{tabular}
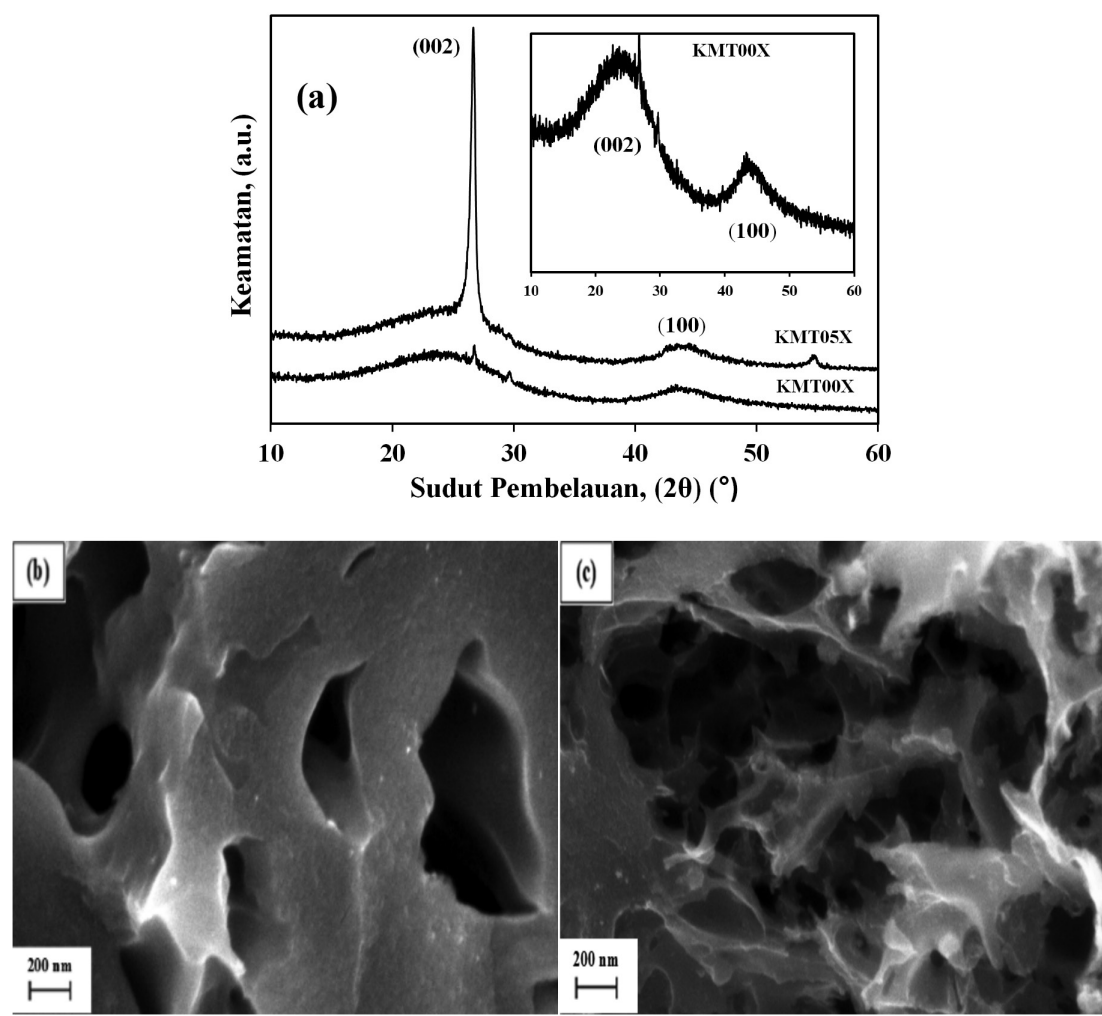

RAJAH 1. (a) Spektrum pembelauan sinar-X bagi sampel serbuk KMT00X dan KMT05X (b) Imej FESEM bagi sampel KMT00X dan (c) KMT05X 

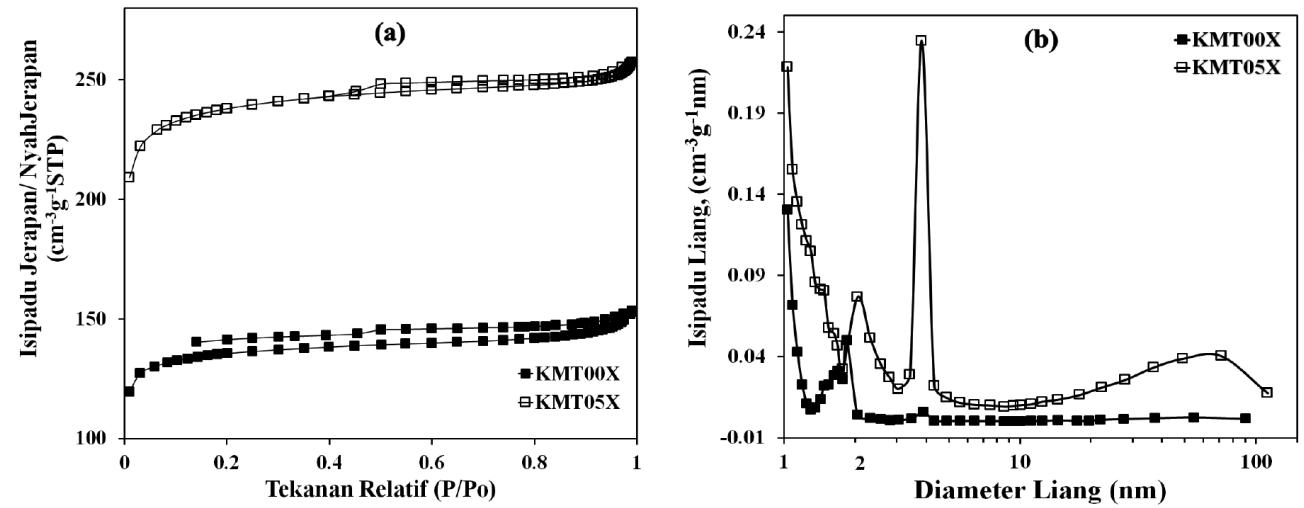

RAJAH 2. (a) Isoterma jerapan-nyahjerapan nitrogen dan (b) Taburan saiz liang bagi sampel KMT00X dan KMT05X

bagi elektrod KMT05X adalah tekal dengan kehadiran ekor pada lengkung isoterma dalam julat $P / P$ menghampiri 1 (Zhou et al. 2017).

Maklumat keliangan sampel serbuk iaitu luas permukaan $\left(\mathrm{S}_{\mathrm{BET}}\right)$, luas permukaan keliangan meso $\left(\mathrm{S}_{\text {meso }}\right)$, luas permukaan keliangan mikro $\left(\mathrm{S}_{\text {micro }}\right)$, isi padu keliangan meso $\left(\mathrm{V}_{\text {meso }}\right)$, isi padu keliangan mikro $\left(\mathrm{V}_{\text {mikro }}\right)$ dan purata diameter keliangan $\left(\mathrm{D}_{\mathrm{p}}\right)$ telah ditentukan daripada data isoterma penjerapan-nyahjerapan dengan menggunakan prosedur piawai (Sing 1985) dan ditunjukkan dalam Jadual 3. Keputusan luas permukaan, $\mathrm{S}_{\mathrm{BET}}$ boleh dikaitkan dengan nilai nisbah $\mathrm{L}_{\mathrm{c}} / \mathrm{L}_{\mathrm{a}}$ dan $\mathrm{L}_{\mathrm{c}} / \mathrm{d}_{002}$ dalam Jadual 2 yang menunjukkan nilai $\mathrm{S}_{\mathrm{BET}}$ bertambah apabila nilai $\mathrm{L}_{\mathrm{c}} / \mathrm{L}_{\mathrm{a}}$ dan $\mathrm{L}_{\mathrm{c}} / \mathrm{d}_{002}$ bertambah. Corak perubahan ini adalah hampir serupa dengan hasil kajian Farma et al. (2013b) yang menggunakan karbon teraktif dengan perbezaan masa pengaktifan antara satu hingga lima jam, yang mendapati bahawa nilai $\mathrm{L}_{\mathrm{c}} / \mathrm{L}_{\mathrm{a}}$ dan $\mathrm{L}_{\mathrm{c}} / \mathrm{d}_{002}$ masing-masing adalah 0.217 dan 2.832, sepadan dengan $\mathrm{S}_{\mathrm{BET}}$ iaitu $1704 \mathrm{~m}^{2} \mathrm{~g}^{-1}$.

Penambahan grafen dalam elektrod KMT05X telah meningkatkan luas permukaan tentu sebanyak $75 \%$ berbanding dengan elektrod tanpa grafen KMT00X. Ini kerana semasa proses pengeringan, karbon teraktif akan mengecut manakala grafen tidak. Oleh itu, liang terhasil dan meningkatkan luas permukaan. Peningkatan luas permukaan tentu sebanyak 8 kali ganda dilaporkan berlaku pada elektrod komposit karbon teraktif yang dicampur dengan grafen (Chen et al. 2012). Selain itu, didapati bahawa isi padu liang dan luas permukaan mikro adalah lebih dominan berbanding dengan isi padu liang dan luas permukaan meso $\left(\mathrm{V}_{\text {mikro }}=84 \%, \mathrm{~V}_{\text {meso }}=16 \% ; \mathrm{S}_{\text {mikro }}=\right.$ $86 \%, \mathrm{~S}_{\text {meso }}=14 \%$ ). Luas permukaan tentu elektrod adalah berhubung kait dengan timbunan tinggi.

\section{SIFAT ELEKTROKIMIA SEL SUPERKAPASITOR}

Rajah 3(a) ialah plot Nyquist bagi semua sel (KMT00KMT40) dalam julat frekuensi daripada $10 \mathrm{mHz}$ hingga $1 \mathrm{MHz}$. Plot ini mengandungi lengkung semibulatan, garis Warburg dan garis kapasitif yang berada dalam julat frekuensi tinggi, pertengahan dan rendah. Menurut Taberna et al. (2003) pada frekuensi tinggi (f $>100 \mathrm{~Hz}$ ), sumber utama rintangan adalah daripada elektrolit dan dua
JADUAL 3. Parameter keliangan sampel KMT00X dan KMT05X

\begin{tabular}{lcc}
\hline \multirow{2}{*}{ Parameter keliangan } & \multicolumn{2}{c}{ Sampel } \\
\cline { 2 - 3 } & KMT00X & KMT05X \\
\hline $\mathrm{S}_{\mathrm{BET}}\left(\mathrm{m}^{2} \mathrm{~g}^{-1}\right)$ & 456 & 798 \\
$\mathrm{~S}_{\text {meso }}\left(\mathrm{m}^{2} \mathrm{~g}^{-1}\right)$ & 64 & 115 \\
$\mathrm{~S}_{\text {mikro }}\left(\mathrm{m}^{2} \mathrm{~g}^{-1}\right)$ & 392 & 683 \\
$\mathrm{~V}_{\text {meso }}\left(\mathrm{cm}^{3} \mathrm{~g}^{-1}\right)$ & 0.043 & 0.059 \\
$\mathrm{~V}_{\text {mikro }}\left(\mathrm{cm}^{3} \mathrm{~g}^{-1}\right)$ & 0.181 & 0.318 \\
$\mathrm{~S}_{\text {meso }} / \mathrm{S}_{\text {mikro }}$ & 0.163 & 0.168 \\
$\mathrm{D}_{\mathrm{p}}(\mathrm{nm})$ & 0.164 & 0.168 \\
\hline
\end{tabular}

elektrod, manakala dalam julat frekuensi pertengahan (1 $\mathrm{Hz}<f<100 \mathrm{~Hz}$ ), sumber utama rintangan adalah daripada pengangkutan/resapan ion dan isyarat elektrik melalui liang elektrod. Plot Nyquist ini mempunyai bentuk yang lazimnya diperoleh daripada superkapasitor berasaskan karbon berliang (Farma et al. 2013b).

Rajah 3(b) menunjukkan kedudukan parameter elektrik ( $E S R / R_{s}, R_{c t}$ dan $\left.R_{p}\right)$ dalam plot Nyquist. ESR atau $R_{s}$ mewakili gabungan rintangan elekrolit dan rintangan sentuh antara pemungut arus dan elektrod. $R_{c t}$ iaitu diameter semibulatan $\left(R_{p}-R_{s}\right)$, mewakili rintangan pemindahan cas yang terhasil daripada gabungan gerak balas terhadap kesan resistif dan kapasitif. Kesan resistif yang melibatkan rintangan elektronik dalam elektrod karbon, rintangan antara muka antara elektrod dan pemungut arus, rintangan larutan elektrolit dan rintangan oleh liang yang kecil terhadap resapan ion melalui liang, adalah lebih dominan berbanding dengan kesan kapasitif.

Nilai $R_{s}, R_{c t}$ dan $R_{p}$ yang diperoleh daripada plot Nyquist ditunjukkan dalam Jadual 4. ESR didapati berubahubah apabila kuantiti kandungan grafen dalam elektrod berubah, tetapi masih berada dalam julat rintangan tipikal bagi elektrolit KOH pada kepekatan ini, iaitu $0.3-0.5 \Omega$ (Jasni et al. 2018). Perubahan ESR berlaku kerana terdapat perubahan pada nilai rintangan sentuh antara pemungut arus dan elektrod. $R_{c t}$ berkurang apabila kandungan grafen dalam elektrod adalah $5 \%$ bt. dan seterusnya meningkat apabila kandungan grafen bertambah. Ini menunjukkan bahawa penambahan grafen dengan kuantiti yang optimum 
dapat mengurangkan dengan signifikan nilai $R_{c t}$. Walau bagaimanapun, nilai $R_{c t}$ yang diperoleh masih berada dalam julat nilai seperti yang telah dilaporkan dalam kajian lain, yang melibatkan penggunaan CNT $(0.3-0.6) \Omega$ (Dolah et al. 2014), grafit (1.0-1.5) $\Omega$ (Nor et al. 2017) dan kok petroleum $(0.5 \Omega)$ (Taer et al. 2011) sebagai bahan tambah dalam elektrod karbon.

Garis Warburg dalam plot Nyquist dapat dilihat dengan lebih jelas dalam Rajah 3(b), yang diplot untuk julat frekuensi daripada $1 \mathrm{MHz}$ hingga $0.15 \mathrm{~Hz}$. Garis Warburg bermula dari titik hujung (kanan) semibulatan dan berakhir pada titik dan garis ini mulai berubah menjadi lebih cerun. Kecerunannya yang ideal ialah $45^{\circ}$. Ia terbentuk oleh kerana wujudnya komponen rintangan pemindahan ion elektrolit dalam liang mikro dan meso dan dalam masa yang sama berlaku peningkatan komponen kapasitif semasa ion elektrolit bergerak dalam liang tersebut (Emmenegger et al. 2003). Kesan kehadiran grafen dalam elektrod dapat dilihat daripada perubahan pada kecerunan dan panjang garis Warburg. Garis Warburg yang pendek dan mempunyai kecerunan yang lebih curam $\left(>45^{\circ}\right)$ menunjukkan komponen kapasitif yang lebih dominan, manakala yang panjang dan mempunyai kecerunan yang lebih landai menunjukkan komponen resistif yang lebih dominan. Sifat garis Warburg yang dipengaruhi oleh bahan tambah CNT dan bahan tambah lain dalam elektrod karbon dapat dilihat dalam banyak kajian, contohnya dalam kajian oleh Dolah et al. (2014), Emmenegger et al. (2003), Nor et al. (2017) dan Soltaninejad et al. (2015). Garis impedans yang lurus dengan kecerunan yang hampir tegak dalam julat frekuensi rendah (Rajah 3(a)), yang bermula dari hujung garis Warburg, menunjukkan bahawa antara muka elektrod/elektrolit dalam sel menunjukkan peningkatan ciri kapasitif apabila frekuensi semakin menurun. Peningkatan yang lebih tinggi adalah sepadan dengan garis impedans yang lebih pendek dan mempunyai kecerunan yang lebih menghampiri infiniti. Peningkatan ini berlaku dalam julat frekuensi rendah disebabkan oleh lebih banyak jumlah cas ionik daripada larutan elektrolit bergerak masuk ke dalam struktur liang elektrod untuk membentuk dwi-lapisan elektrik pada antara muka elektrod/elektrolit. Ini kerana pada frekuensi rendah, cas ionik mempunyai masa yang mencukupi untuk memasuki dan mengisi liang elektrod. Pengumpulan cas dwi-lapisan yang mencukupi pada antara muka elektrod/elektrolit ini boleh membantu sel untuk mencapai kapasitans elektrik yang maksimum. Seperti yang ditunjukkan dalam Rajah 3(b), ciri garis impedans kapasitif dipengaruhi oleh peratus berat kandungan grafen dalam elektrod. Plot Nyquist sel KMT05 menunjukkan nilai $Z$ " paling rendah berbanding sel-sel yang lain pada frekuensi minimum iaitu $10 \mathrm{mHz}$. Nilai $C_{s p}$ yang dihitung daripada garis impedans kapasitif (frekuensi terendah $=$ $10 \mathrm{mHz}$ ) untuk setiap sel menggunakan persamaan (1) menunjukkan bahawa nilai $C_{s p}$ sel KMT05 adalah lebih tinggi berbanding dengan sel yang lain (Jadual 5).

Kapasitans tentu, $C_{s p}$ ialah parameter elektrokimia yang bersandar kepada masa oleh kerana pembentukan cas dwi-lapisan elektrik pada antara muka elektrod/elektrolit adalah proses yang bergantung kepada masa, seperti yang dibuktikan oleh kewujudan kecerunan garis impedans kapasitif (Rajah 3(a)). Sifat ini dapat dijelaskan secara kuantitatif oleh (1), (2) dan (3). Rajah 3(d) menunjukkan perubahan $C_{s p}$ yang diperoleh menggunakan (1). Didapati bahawa dalam julat frekuensi rendah, $C_{s p}$ berkurang apabila kandungan berat grafen dalam elektrod melebihi 5\%, rajah ini menunjukkan bahawa $C_{s p}$ sangat bersandar kepada frekuensi, tentunya dalam julat frekuensi di bawah $1 \mathrm{~Hz}$. Dalam julat frekuensi ini, tahap kebersandaran ini didapati berkurangan apabila kandungan berat grafen dalam elektrod melebihi 5\%. Manakala dalam julat frekuensi tinggi pula, nilai $C_{s p}$ tidak berubah secara ketara dengan perubahan kandungan berat grafen dan frekuensi.

Graf kapasitans khayalan, $C^{\prime \prime}$ melawan frekuensi dalam Rajah 3(e) menunjukkan puncak pada nilai frekuensi gerak balas, $f_{o}$. Daripada nilai $f_{o}$, nilai pemalar masa gerak balas, $\tau_{\mathrm{o}}$, yang merupakan sempadan antara kelakuan kapasitif dengan resistif suatu kapasitor, telah dihitung melalui persamaan $\tau_{o}=1 / f_{o}$, dan disenaraikan dalam Jadual 4 untuk semua sel. Nilai-nilai yang diperoleh adalah setara dengan yang telah dilaporkan dalam kajian lain, contohnya kajian oleh Farma et al. (2013a) 25 - 50 s, Nor et al. (2017) 1 - 8 s dan Soltaninejad et al. (2015) 9 - 11 s; yang masing-masing menggunakan bahan tambah CNT, grafit dan polipirol. Nilai $\tau_{o}$ didapati dipengaruhi oleh peratus berat grafen dalam elektrod, dengan nilai terendah $2.5 \mathrm{~s}$ dimiliki oleh sel KMT05 dan ini menunjukkan bahawa sel ini mempunyai penghantaran kuasa yang paling tinggi.

Rajah 4(a) menunjukkan perbandingan bentuk lengkung CV untuk sel KMT00 hingga sel KMT40 yang telah direkodkan pada kadar imbasan $1 \mathrm{mV} \mathrm{s}^{-1}$. Semua sel menunjukkan bentuk lengkung CV hampir segi empat tepat yang memperlihatkan ciri-ciri prestasi kapasitif elektrod. Walau bagaimanapun, luas kawasan lengkung CV didapati berubah dengan peningkatan kandungan grafen dalam KMT. Luas lengkung CV untuk KMT05 adalah yang paling besar dan memberikan $C_{s p}$ yang paling tinggi. KMT05 menunjukkan kitaran keterbalikan dan kapasitans elektrod dwi-lapisan yang tinggi sepanjang proses casdiscas berbanding sel yang lain. Nilai $C_{s p}$ yang diperoleh daripada rajah ini ditunjukkan dalam Jadual 5.

Graf $C_{s p}$ melawan kadar imbasan untuk KMT00 hingga KMT40 yang ditunjukkan dalam Rajah 4(b). Seperti yang dijangka, KMT05 menunjukkan prestasi terbaik daripada segi penyusutan $C_{s p}$, sebanyak $\sim 82 \%$, iaitu $216 \mathrm{~F} \mathrm{~g}^{-1}$ pada $1 \mathrm{mV} \mathrm{s}^{-1}$ dan $40 \mathrm{~F} \mathrm{~g}^{-1}$ pada $100 \mathrm{mV} \mathrm{s}^{-1}$. Nilai $C_{s p}$ berkurang apabila kadar imbasan meningkat kerana keterbatasan resapan ion yang memerlukan masa yang lebih lama untuk meresap ke dalam liang elektrod bagi membentuk elektrod dwi-lapisan dan seterusnya meningkatkan nilai kapasitans. Ini menunjukkan bahawa penambahan $5 \%$ bt. grafen dalam KMT memberikan sumbangan optimum bagi peningkatan prestasi kapasitif dan memperlihatkan kapasitans elektrokimia yang lebih baik daripada sel-sel lain. Bagi grafen teraktif dirawat $\mathrm{KOH} / \mathrm{komposit}$ karbon dan kepingan karbon nano/komposit grafen, penyusutan $C_{s p}$ adalah sebanyak 15-60\% (Liu et al. 2016). 

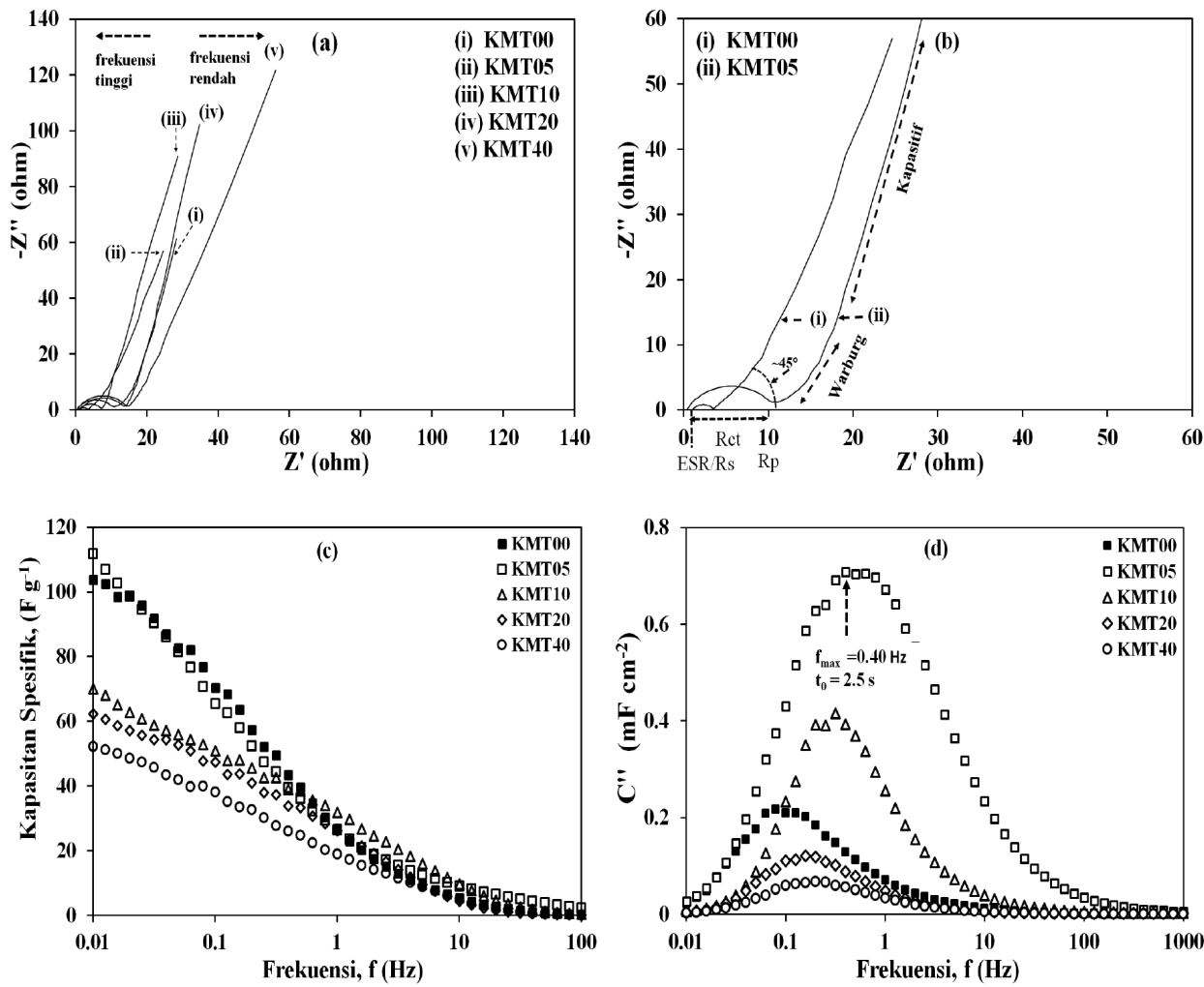

RAJAH 3. (a) Plot Nyquist dalam julat frekuensi daripada $1 \mathrm{MHz}$ ke $10 \mathrm{mHz}$, (b) sisipan plot Nyquist kepada Rajah 3(a), (c) Graf kapasitan tentu melawan frekuensi dan

(d) Graf kapasitan khayalan (C") melawan frekuensi bagi semua sel

JADUAL 4. Nilai parameter elektrik semua sel superkapasitor daripada data EIS

\begin{tabular}{lccccc}
\hline Sampel & $E S R(\Omega)$ & $R_{p}(\Omega)$ & $R_{c t}(\Omega)$ & $f_{\max }(\mathrm{Hz})$ & $t_{0}(\mathrm{~s})$ \\
\hline KMT00 & 0.51 & 10.76 & 10.25 & 0.10 & 10.00 \\
KMT05 & 1.12 & 3.51 & 2.39 & 0.40 & 2.50 \\
KMT10 & 1.03 & 12.59 & 11.56 & 0.32 & 3.10 \\
KMT20 & 1.20 & 13.82 & 12.62 & 0.25 & 4.00 \\
KMT40 & 0.55 & 14.67 & 14.11 & 0.20 & 5.00 \\
\hline
\end{tabular}

Rajah 4(c) menunjukkan lengkung CV bagi sel KMT05 pada kadar imbasan 1 hingga $100 \mathrm{mV} \mathrm{s}^{-1}$. Pada kadar imbasan yang rendah, bentuk lengkung $\mathrm{CV}$ adalah hampir segi empat tepat serta mempunyai arus voltametri yang rendah, manakala apabila kadar imbasan meningkat, lengkung CV menyimpang/tersisih daripada bentuk segi empat pada julat voltan $0.85 \mathrm{~V}$ hingga $1.0 \mathrm{~V}$. Ini menunjukkan kadar keupayaan prestasi sel yang lemah.

Rajah 5(a) menunjukkan lengkung GCD yang direkod pada ketumpatan arus $10 \mathrm{~mA} \mathrm{~cm}^{-2}$ untuk semua sel superkapasitor. Semua lengkung menunjukkan bentuk segi tiga hampir simetri yang merupakan bentuk lazim untuk sel superkapasitor berasaskan elektrod karbon berliang (Farma et al. 2013b). Walaupun lengkung GCD ini mempunyai bentuk yang serupa tetapi lebar tapak segi tiga lengkung ini berbeza. Ini menunjukkan bahawa kehadiran grafen dalam elektrod memberi kesan terhadap masa cas/nyahcas sel superkapasitor. Masa nyahcas yang lama bagi sesuatu sel superkapasitor menunjukkan sifat kapasitans yang lebih baik (Chee et al. 2014). Nilai $C_{s p}$ yang telah diperoleh daripada lengkung EIS, CV dan GCD dengan menggunakan (1), (2) dan (3) masing-masing ditunjukkan dalam Jadual 5. Berbanding dengan sel yang lain, sel KMT05 mempunyai nilai $C_{s p}$ tertinggi, yang menunjukkan peningkatan peratus $C_{s p}$ sebanyak $\sim 164 \%$ berbanding dengan sel yang menggunakan elektrod tanpa grafen. Keputusan $C_{s p}$ (GCD) ini adalah tekal dan selaras dengan corak perubahan dengan nilai $C_{s p}$ yang diperoleh daripada data EIS dan CV.

Selain daripada nilai $C_{s p}$, nilai ESR juga boleh diperoleh daripada data GCD, iaitu daripada voltan susut yang berlaku pada titik permulaan lengkung discas (Rajah 6(a)) dengan menggunakan persamaan; ESR = $\frac{(I R)_{\text {susut }}}{2 i}$, dengan $i$ adalah arus discas; dan $(I R)_{\text {susut }}$ adalah nilai voltan susut. Nilai ESR yang diperoleh untuk 

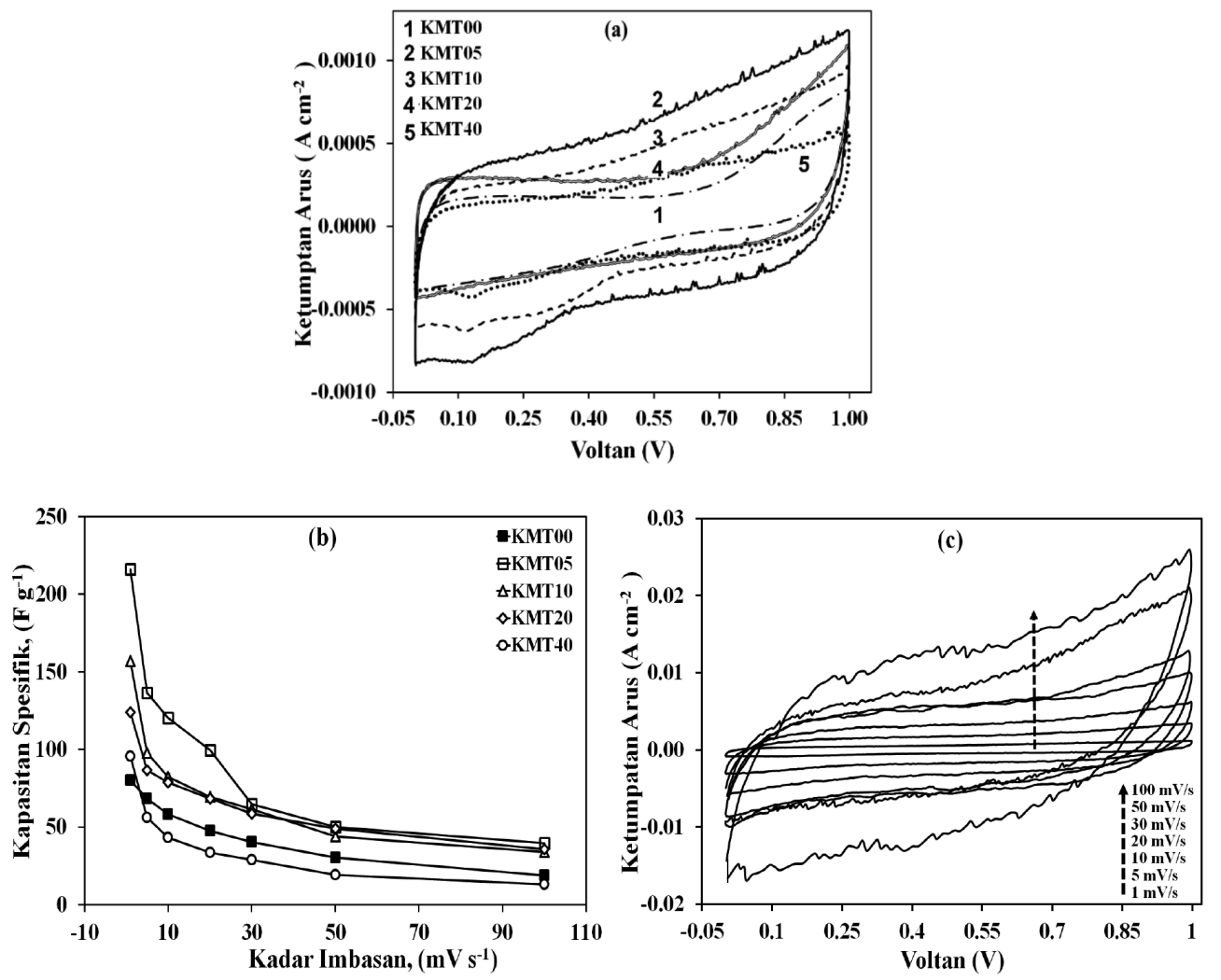

RAJAH 4. (a) Profil CV bagi semua sel yang direkod pada kadar $1 \mathrm{mV} \mathrm{s}^{-1}$, (b) Kapasitans tentu bagi semua sel pada kadar imbasan 1 - $100 \mathrm{mV} \mathrm{s}^{-1}$ (c) Profil CV KMT05 pada kadar imbasan 1 - $100 \mathrm{mV} \mathrm{s}^{-1}$
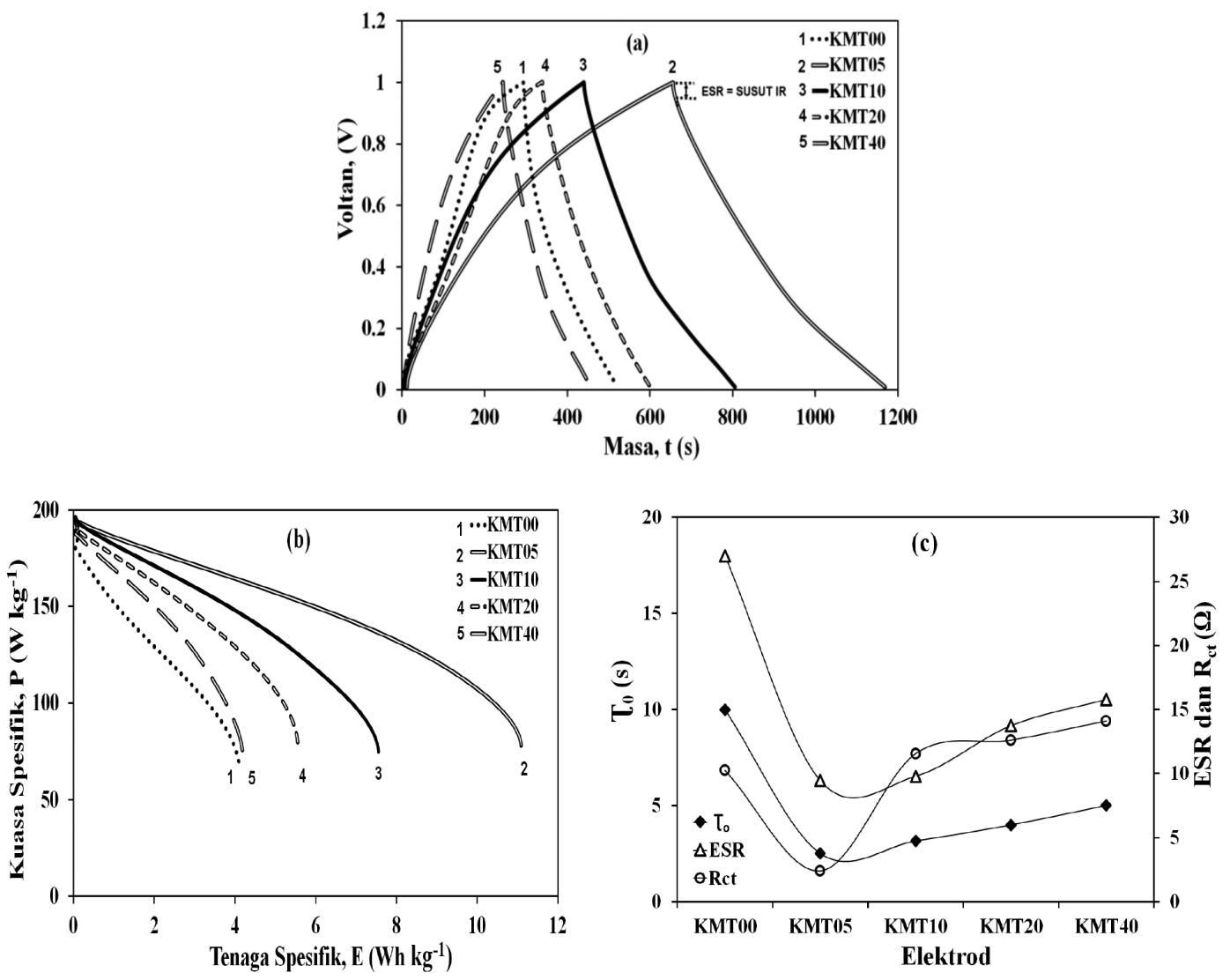

RAJAH 5. (a) Lengkung cas-discas pada arus $1 \mathrm{~mA} \mathrm{~cm}^{-2}$ (b) Plot Ragon dan

(c) Korelasi antara $\tau_{o}, R_{c t}$ dan ESR bagi semua sel 
semua sel ditunjukkan dalam Jadual 5, didapati berubah mengikut peratus kandungan grafen dalam elektrod. Sel KMT05 didapati mempunyai nilai ESR yang terendah. Ini menunjukkan bahawa 5\% grafen dalam elektrod adalah optimum untuk menghasilkan nilai ESR yang terbaik untuk elektrod. Corak perubahan nilai ESR yang diperoleh daripada data GCD (Jadual 5) yang disebabkan oleh perubahan kuantiti grafen dalam elektrod didapati tekal dengan corak perubahan nilai $R_{c t}$ dan ini didapati selaras dengan corak perubahan nilai $\mathrm{R}_{\mathrm{s}}$ yang ditentukan daripada data EIS seperti yang ditunjukkan dalam Jadual 4. Nilai ESR yang diperoleh adalah setanding atau dalam lingkungan nilai ESR yang dilaporkan oleh kajian lain dengan menggunakan komposit karbon-grafit iaitu 2 - 12 $\Omega$ (Nor et al. 2017) dan komposit karbon-CNT 0.26-1.46 $\Omega$ (Dolah et al. 2014) . Nilai kuasa tentu, $P_{s p}$ dan tenaga tentu, $E_{s p}$ bagi semua sel yang telah ditentukan daripada data GCD menggunakan (4) dan (5) ditunjukkan sebagai plot Ragon dalam Rajah 5(b). Plot ini menunjukkan bahawa kuasa tentu berkurangan apabila tenaga tentu semakin meningkat, dengan corak pengurangan bergantung kepada peratus kandungan grafen dalam KMT. Bagi sel KMT05, peningkatan tenaga tentunya diikuti oleh pengurangan kuasa tentu yang lebih kecil berbanding dengan sel-sel yang lain. Nilai tenaga tentu maksimum $\left(E_{m a k}\right)$ dan kuasa tentu maksimum $\left(P_{\text {mak }}\right)$ bagi semua sel yang ditunjukkan dalam Jadual 5 menunjukkan sel KMT05 memperlihatkan prestasi yang optimum.
Peratus peningkatan kapasitans tentu, kuasa tentu dan tenaga tentu yang disebabkan oleh penambahan bahan tambah grafen dengan peratusan yang optimum (sel KMT05) dalam elektrod, dibandingkan dengan keputusan kajian penyelidik lain seperti yang ditunjukkan dalam Jadual 6. Keputusan kajian ini menunjukkan peratus peningkatan $C_{s p}$ bagi sel adalah jauh lebih tinggi iaitu 164\% berbanding dengan keputusan kajian penyelidik lain (Fan et al. 2014; Liu et al. 2016; Zhou et al. 2017) dan juga tidak jauh bezanya dengan keputusan kajian oleh Jiang et al. (2013), Xie et al. (2016) dan Zheng et al. (2014). Data dalam jadual ini juga menunjukkan bahawa peratus peningkatan $P_{\text {mak }}$ yang ditunjukkan oleh sel KMT05 kelihatan lebih rendah daripada nilai-nilai yang dilaporkan oleh kajian lain, manakala daripada segi $E_{m a k}$, sel ini menunjukkan peratus peningkatan yang lebih tinggi berbanding dengan keputusan kajian lain.

Prestasi terbaik sel KMT05 adalah tekal dengan corak korelasi yang baik antara $\tau_{o}, R_{c t}$ dan ESR (GCD) seperti yang ditunjukkan dalam plot $\tau_{o}, R_{c t}$ dan ESR (GCD) melawan peratus kandungan grafen dalam elektrod (Rajah 5(c)). Nilai minimum bagi kesemua lengkungan dalam graf adalah apabila elektrod mengandungi $5 \%$ bt. grafen. Korelasi yang sama telah dilaporkan untuk elektrod karbon yang ditingkatkan prestasinya menggunakan bahan tambah grafit (Nor et al. 2017) dan CNT (Dolah et al. 2014).

JADUAL 5. Nilai kapasitans tentu, kuasa tentu, tenaga tentu, dan ESR

bagi semua sel yang diperoleh daripada kaedah yang berbeza

\begin{tabular}{lcccccc}
\hline Kaedah & EIS & CV & & GCD & \\
\hline Sampel & & $\mathrm{C}_{\mathrm{sp}}\left(\mathrm{F} \mathrm{g}^{-1}\right)$ & & $\operatorname{ESR}(\Omega)$ & $\mathrm{P}\left(\mathrm{W} \mathrm{kg}^{-1}\right)$ & $\mathrm{E}\left(\mathrm{Wh} \mathrm{kg}^{-1}\right)$ \\
\hline KMT00 & 104 & 80 & 65 & 27.00 & 189.19 & 4.10 \\
KMT05 & 112 & 216 & 172 & 9.45 & 196.13 & 11.08 \\
KMT10 & 70 & 157 & 109 & 9.80 & 196.24 & 7.55 \\
KMT20 & 62 & 124 & 85 & 13.75 & 194.53 & 5.56 \\
KMT40 & 52 & 96 & 63 & 15.80 & 193.70 & 4.19 \\
\hline
\end{tabular}

JADUAL 6. Perbandingan peratus peningkatan kapasitans tentu, kuasa tentu dan tenaga tentu, kesan daripada modifikasi elektrod ( $\mathrm{TG}=$ tanpa grafen, $\mathrm{G}=$ dengan grafen, $\%=$ peratus peningkatan)

\begin{tabular}{|c|c|c|c|c|c|c|c|c|c|c|}
\hline \multirow[t]{2}{*}{ Komposisi elektrod } & \multicolumn{3}{|c|}{$C_{s p}\left(\mathrm{~F} \mathrm{~g}^{-1}\right)$} & \multicolumn{3}{|c|}{$P_{m a k}\left(\mathrm{~W} \mathrm{~kg}^{-1}\right)$} & \multicolumn{3}{|c|}{$E_{m a k}\left(\mathrm{Wh} \mathrm{kg}^{-1}\right)$} & \multirow[t]{2}{*}{ Rujukan } \\
\hline & TG & $\mathrm{G}$ & $\%$ & TG & G & $\%$ & TG & G & $\%$ & \\
\hline SKSM $+5 \%$ bt. Grafen & 65 & 172 & 164 & 189 & 196.1 & 3.8 & 4 & 11.08 & 170 & Kajian terkini \\
\hline Karbon fiber/grafen & 200 & 553 & 177 & 48 & 50 & 5 & 7 & 17.1 & 144 & (Xie et al. 2016) \\
\hline Karbon kepingan nano/grafen & 140 & 168 & 20 & 1200 & 1250 & 5 & 5 & 8.5 & 89 & (Liu et al. 2016) \\
\hline Karbon teraktif/grafen & 76 & 210 & 176 & 20 & 33.2 & 66 & 13 & 22.3 & 78 & (Zheng et al. 2014) \\
\hline $\begin{array}{l}\text { Karbon berliang nitrogen dan } \\
\text { oksigen/grafen }\end{array}$ & 300 & 380 & 27 & 14.7 & 25.0 & 70 & 8 & 13.2 & 69 & (Zhou et al. 2017) \\
\hline Karbon-nitrogen/grafen & 250 & 300 & 20 & 20 & 22.5 & 12.5 & 6 & 8.4 & 40 & (Fan et al. 2014) \\
\hline $\begin{array}{l}\text { Karbon teraktif glukosa/ } \\
\text { grafen oksida }\end{array}$ & 100 & 334 & 234 & - & 1000 & - & - & 10 & - & (Jiang et al. 2013) \\
\hline
\end{tabular}




\section{KESIMPULAN}

Dalam kajian ini, KMT telah dikomposit dengan bahan tambah 5 - $40 \%$ bt. grafen serta ditambah perekat PVDFHFP dan karbon hitam untuk menghasilkan elektrod superkapasitor. Pencirian elektrokimia menggunakan elektrolit $\mathrm{KOH} 6 \mathrm{M}$ didapati menghasilkan prestasi terbaik bagi sel superkapasitor dengan elektrod yang mengandungi $5 \%$ bt. grafen (KMT05) iaitu kapasitans tentu sebanyak $164 \%$ dan kuasa tentu sebanyak $170 \%$ apabila dibandingkan dengan elektrod tanpa grafen (KMT00). Pengurangan rintangan pemindahan cas, $R_{c t}$ dan rintangan siri setara, ESR bagi elektrod komposit ini dapat menghasilkan masa respons, $\tau_{o}$ yang rendah iaitu $2.5 \mathrm{~s}$. Peningkatan prestasi sifat elektrokimia ini turut selaras dengan keputusan yang diperoleh daripada analisis keliangan serbuk KMT dengan $5 \%$ bt. grafen yang telah menyumbangkan hampir $200 \%$ peningkatan $S_{B E T,} S_{\text {meso }}$ dan $S_{\text {mikro }}$. Kesimpulannya, keputusan daripada kajian ini menunjukkan bahawa kandungan optimum grafen iaitu 5 $\%$ bt. boleh diaplikasikan dalam KMT untuk meningkatkan keliangan elektrod supaya mempunyai luas permukaan yang lebih besar dan membawa kepada penghasilan elektrod superkapasitor yang lebih berkualiti.

\section{PENGHARGAAN}

Pengarang merakamkan penghargaan kepada penaja geran daripada Kementerian Pengajian Tinggi (FRGS/1/2016/ STG07/UKM/02/2), (FRGS/2/2013/ST05/UKM/01/1), Universiti Kebangsaan Malaysia (DIP-2014-027) dan bantuan sokongan daripada CRIM (Pusat Pengurusan Penyelidikan dan Inovasi), UKM. Pengarang juga berterima kasih kepada Encik Saini atas sokongan beliau dalam kerja-kerja makmal dan Fakulti Sains dan Teknologi, UKM.

\section{RUJUKAN}

Awitdrus., Deraman, M., Talib, I.A., Omar, R., Jumali, M.H.H., Taer, E. \& Saman, M.M. 2010. Microcrystallite dimension and total active surface area of carbon electrode from mixtures of pre-carbonized oil palm empty fruit bunches and green petroleum cokes. Sains Malaysiana 39(1): 83-86.

Ban, S., Zhang, J., Zhang, L., Tsay, K., Song, D. \& Zou, X. 2013. Charging and discharging electrochemical supercapacitors in the presence of both parallel leakage process and electrochemical decomposition of solvent. Electrochimica Acta 90: 542-549.

Barsykov, V. \& Khomenko, V. 2010. The influence of polymer binders on the performance of cathodes for lithium-ion batteries. Scientific Journal of Riga Technical University 21: 67-71.

Chee, W.K., Lim, H.N. \& Huang, N.M. 2014. Electrochemical properties of free-standing polypyrrole/graphene oxide/zinc oxide flexible supercapacitor. Int. J. Energ. Res. 31(2007): 135-147.

Chen, Y., Zhang, X., Zhang, H., Sun, X., Zhang, D. \& Ma, Y. 2012. High-performance supercapacitors based on a graphene-activated carbon composite prepared by chemical activation. RSC Advances 2(20): 7747-7753.
Deraman, M., Ishak, M.M., Farma, R., Awitdrus, Taer, E., Talib, I.A. \& Omar, R. 2011. Binderless composite electrode monolith from carbon nanotube and biomass carbon activated by $\mathrm{H}_{2} \mathrm{SO}_{4}$ and $\mathrm{CO}_{2}$ gas for supercapacitor. AIP Conference Proceedings 1415: 175-179.

Deraman, M., Awitdrus, Talib, I.A., Omar, R., Jumali, M.H.H., Ishak, M.M., Saad, S.K.M., Taer, E., Saman, M.M., Farma, R. \& Yunus, R.M. 2010. Electrical conductivity of carbon pellets prepared from mixtures of pyropolymers from oil palm bunches and petroleum green coke. AIP Conference Proceedings 50: 50-53.

Deraman, M., Zakaria, S. \& Murshidi, J.A. 2001. Estimation of crystallinity and crystallite size of cellulose in benzylated fibres of oil palm empty fruit bunches by X-ray diffraction. Japanese Journal of Applied Physics 40: 3311-3314.

Dolah, B.N.M., Deraman, M., Othman, M.A.R., Farma, R., Taer, E., Awitdrus, Basri, N.H., Talib, I.A., Omar, R. \& Nor, N.S.M. 2014. A method to produce binderless supercapacitor electrode monoliths from biomass carbon and carbon nanotubes. Materials Research Bulletin 60: 10-19.

Dong, X., Xu, H., Wang, X., Huang, Y., Chan-Park, M.B. \& Zhang, H., Wang,L., Huang, W. \& Chen, P. 2012.3D graphene à cobalt oxide electrode for high-performance supercapacitor and enzymeless glucose detection ACS Nano 6(4): 3206-3213.

Emmenegger, C., Mauron, P., Sudan, P., Wenger, P., Hermann, V., Gallay, R. \& Zuttel, J. 2003. Investigation of electrochemical double-layer (ECDL) capacitors electrodes based on carbon nanotubes and activated carbon materials. Journal of Power Sources 124(1): 321-329.

Fan, X., Yu, C., Yang, J., Ling, Z. \& Qiu, J. 2014. Hydrothermal synthesis and activation of graphene-incorporated nitrogenrich carbon composite for high-performance supercapacitors. Carbon 70: 130-141.

Farma, R., Deraman, M., Awitdrus, Talib, I.A., Omar, R., Manjunatha, J.G., Ishak, M.M., Basri, N.H. \& Dolah, B.N.M. 2013a. Physical and electrochemical properties of supercapacitor composite electrodes prepared from biomass carbon. International Journal of Electrochemical Science 8: 257-273.

Farma, R., Deraman, M., Awitdrus, A., Talib, I.A., Taer, E., Basri, N.H., Manjunatha, J.G., Ishak, M.M., Dolah, B.N.M. \& Hashmi, S.A. 2013b. Preparation of highly porous binderless activated carbon electrodes from fibres of oil palm empty fruit bunches for application in supercapacitors. Bioresource Technology 132: 254-261.

Gonzlez, A., Goikolea, E., Barrena, J.A. \& Mysyk, R. 2016. Review on supercapacitors: Technologies and materials. Renewable and Sustainable Energy Reviews 58: 1189-1206.

Gu, W. \& Yushin, G. 2014. Review of nanostructured carbon materials for electrochemical capacitor applications: Advantages and limitations of activated carbon, carbidederived carbon, zeolite-templated carbon, carbon aerogels, carbon nanotubes, onion-like carbon, and graphene. Advanced Reviews 3: 424-473.

Ho, M.Y., Khiew, P.S., Isa, D., Tan, T.K., Chiu, W.S., Chia, C.H., Hamid, M.A.A. \& Shamsudin, R. 2014. $\mathrm{Nano} \mathrm{Fe}_{3} \mathrm{O}_{4}^{-}$ activated carbon composites for aqueous supercapacitors. Sains Malaysiana 43(6): 885-894.

Jasni, M.R.M., Deraman, M., Suleman, M., Zainuddin, Z., Othman, M.A.R., Chia, C.H. \& Hashim, M.A. 2017. Supercapacitor electrodes from activation of binderless green monoliths of biomass self-adhesive carbon grains composed of varying amount of graphene additive. Ionics 24(4): 1195-1210. 
Jasni, M.R.M., Deraman, M., Hamdan, E., Sazali, N.E.S., Nor, N.S.M., Ishak, M.M., Basri, N.H., Omar, R., Othman, M.A.R., Zulkifli, R., Daik, R. \& Suleman. M. 2016a. Effect of KOH treated graphene in green monoliths of pre-carbonized biomass fibers on the structure, porosity and capacitance of supercapacitors carbon electrodes. Material Science Forum 846: 551-558.

Jasni, M.R.M., Deraman, M., Suleman, M., Hamdan, E., Sazali, N.E.S., Nor, N.S.M. \& Shamsudin, S.A. 2016b. Effect of nano-scale characteristics of graphene on electrochemical performance of activated carbon supercapacitor electrodes. AIP Conference Proceedings 1710: 300341-300349.

Jiang, L., Yan, J., Zhou, Y., Hao, L., Xue, R., Jiang, L. \& Yi, B. 2013. Activated carbon/graphene composites with highrate performance as electrode materials for electrochemical capacitors. Journal of Solid State Electrochemistry 17(11): 2949-2958.

Ke, Q. \& Wang, J. 2016. Graphene-based materials as supercapacitor electrodes - A review. Journal of Materiomics 2: 37-54.

Kim, T., Jung, G., Yoo, S., Suh, K.S. \& Ruoff, R.S. 2013. Activated graphene-based carbons as supercapacitor electrodes with macro- and mesopores. ACS Nano 7(8): 6899-6905.

Liu, D., Jia, Z. \& Wang, D. 2016. Preparation of hierarchically porous carbon nanosheet composites with graphene conductive scaffolds for supercapacitors: An electrostaticassistant fabrication strategy. Carbon 100: 664-677.

Nor, N.S.M., Deraman, M., Omar, R., Awitdrus, Farma, R., Basri, N.H., Dolah, B.N.M., Mamat, N.F., Yatim, B. \& Daud, M.N.M. 2015. Influence of gamma irradiation exposure on the performance of supercapacitor electrodes made from oil palm empty fruit bunches. Energy 79: 183-194.

Nor, N.S.M., Deraman, M., Suleman, M., Jasni, M.R.M., Manjunatha J.G., Othman, M.A.R. \& Shamsudin S.A. 2017. Supercapacitors using Binderless activated carbon monoliths electrodes consisting of a graphite additive and pre-carbonized biomass fibers. International Journal of Electrochemical Science 12: 2520-2539.

Qu, D. 2002. Studies of the activated carbons used in double-layer supercapacitors. Journal of Power Sources 109(2): 403-411.

Sevilla, M. \& Mokaya, R. 2014. Energy storage applications of activated carbons: Supercapacitors and hydrogen storage. Energy Environment Science 7: 1250-1280.

Sing, K.S.W. 1985. Reporting physisorption data for gas/solid systems with special reference to the determination of surface area and porosity. Pure and Applied Chemistry 57(4): 603619.

Soltaninejad, S., Daik, R., Deraman, M., Chin, Y.C., Nor, N.S.M., Sazali, N.E.S., Hamdan, E., Jasni, M.R.M., Ishak, M.M., Noroozi, M. \& Suleman, M. 2015. Physical and electrochemical characteristics of carbon monoliths electrodes from activation of pre-carbonized fibers of oil palm empty fruit bunches added with varying amount of polypyrrole. International Journal of Electrochemical Science 10: 1052410542.

Sulaiman, K.S., Mat, A. \& Arof, A.K. 2016. Activated carbon from coconut leaves for electrical double-layer capacitor. Ionics 22(6): 911-918.

Taberna, P.L., Simon, P. \& Fauvarque, J.F. 2003. Electrochemical characteristics and impedance spectroscopy studies of carboncarbon supercapacitors. Journal of the Electrochemical Society 150(3): A292-A300.

Taer, E., Deraman, M., Talib, I.A., Awitdrus, A., Hashmi, S.A. \& Umar, A.A. 2011. Preparation of a highly porous binderless activated carbon monolith from rubber wood sawdust by a multi-step activation process for application in supercapacitors. International Journal of Electrochemical Science 6: 3301-3315.

Taer, E., Deraman, M., Talib, I.A., Umar, A.A., Oyama, M. \& Yunus, R.M. 2010. Physical, electrochemical and supercapacitive properties of activated carbon pellets from pre-carbonized rubber wood sawdust by $\mathrm{CO}_{2}$ activation. Current Applied Physics 10: 1071-1075.

Tsay, K.C., Zhang, L. \& Zhang, J. 2012. Effects of electrode layer composition/thickness and electrolyte concentration on both specific capacitance and energy density of supercapacitor. Electrochimica Acta 60: 428-436.

Wang, H.Q., Yin, J.,Li, Q. \& Yin, P. 2014. Current progress on the preparation of binders for electrochemical supercapacitors. PostDoc Journal: Journal of Postdoctoral Research 2(1): 31-238.

Wei, L., Sevilla, M., Fuertes, A.B., Mokaya, R. \& Yushin, G. 2012. Polypyrrole-derived activated carbons for highperformance electrical double-layer capacitors with ionic liquid electrolyte. Advanced Functional Materials 22(4): 827-834.

Xie, Q., Bao, R., Xie, C., Zheng, A., Wu, S., Zhang, Y., Zhang, R. \& Zhao, P. 2016. Core-shell N-doped active carbon fiber@ graphene composites for aqueous symmetric supercapacitors with high-energy and high-power density. Journal of Power Sources 317: 133-142.

Xu, Y., Chang, L. \& Hu, Y.H. 2016. KOH-assisted microwave post-treatment of activated carbon for efficient symmetrical double-layer capacitors. International Journal of Energy Research 41: 728-735.

Xu, Y., Lin, Z., Huang, X., Liu, Y., Huang, Y. \& Duan, X. 2013. Flexible solid-state supercapacitors based on threedimensional ACS Nano 7(5): 4042-4049.

Zheng, C., Zhou, X., Cao, H., Wang, G. \& Liu, Z. 2014. Synthesis of porous graphene/activated carbon composite with high packing density and large specific surface area for supercapacitor electrode material. Journal of Power Sources 258: 290-296.

Zhong, C., Deng, Y., Hu, W., Qiao, J., Zhang, L. \& Zhang, J. 2015. A review of electrolyte materials and compositions for electrochemical supercapacitors. Chem. Soc. Rev. 44: 7484-7539.

Zhou, S., Xie, Q., Wu, S., Huang, X. \& Zhao, P. 2017. Influence of graphene coating on supercapacitive behavior of sandwichlike $\mathrm{N}$ - and $\mathrm{O}$-enriched porous carbon/graphene composites in aqueous and organic electrolytes. Ionics 1: 1-9.

Zhu, Y., Murali, S., Cai, W., Li, X., Suk, J.W., Potts, J.R. \& Ruoff, R.S. 2010. Graphene and graphene oxide: Synthesis, properties, and applications. Advanced Materials 22: 39063924.

School of Applied Physics

Faculty of Science and Technology

Universiti Kebangsaan Malaysia

43600 UKM Bangi, Selangor Darul Ehsan

Malaysia

*Pengarang untuk surat-menyurat; email: zazai@ukm.edu.my

Diserahkan: 14 Julai 2018

Diterima: 10 Oktober 2018 